Apuntes Universitarios, 2020: 10(4), octubre-diciembre

ISSN: 2304-0335 DOI:https://doi.org/10.17162/au.v10i4.499

\title{
Estudio sociológico sobre el efecto de las características de la modernidad en la identidad étnica
}

\section{Sociological study about the effect of modernity characteristics on the ethnic identity}

\author{
Talieh Khademian ${ }^{1 \mathrm{a}}$, Naser Rezapour ${ }^{2}$ y Hamid Pouryousefi ${ }^{3}$ \\ Islamic Azad University, Tehran, Iran ${ }^{123}$ \\ Orcid ID: https://orcid.org/0000-0002-4402-0084 ${ }^{1}$ \\ Orcid ID: https://orcid.org/0000-0001-9028-8770² \\ iD Orcid ID: https://orcid.org/0000-0003-4076-6038 3
}

Recibido: 09 de enero de 2020

Aceptado: 04 de agosto de 2020

\begin{abstract}
Resumen
La etnicidad y la nacionalidad son tipos de identidades sociales modernas que han sido reformadas después de ser globalizadas. Esta investigación busca estudiar el papel de las características de la modernidad en la identidad étnica. Los datos de la investigación se recopilaron mediante un cuestionario elaborado por un investigador, y 384 estudiantes de la Universidad Islámica Azad, Teherán North Branch fueron seleccionados por muestreo aleatorio no probabilístico en 2019. Los resultados muestran la relación significativa entre la identidad étnica y las características de la modernidad, estilo de vida moderno $(r=-0.66)$, identidad moderna $(\mathrm{r}=-0.74)$, socialización moderna $(\mathrm{r}=-0.40)$ y uso intencionado de redes sociales virtuales $(r=0.31)$. En otras palabras, las identidades étnicas se debilitan por la tendencia de los participantes a los patrones y valores beneficiosos e individualistas occidentales adaptados con la ley, evitando y subestimando las normas religiosas y tradicionales. Mientras tanto, las redes sociales virtuales como herramienta de modernidad han sido una oportunidad para expresar las demandas étnicas políticas y sociales, en particular los hombres de la frontera como los kurdos y los turcos. Principalmente, han aparecido en forma de movimientos dramáticos y tensiones interétnicas que al seguir los elementos de la modernidad finalmente disminuyen las pertenencias étnicas y la tendencia a la identidad global, y solo el uso deliberado y consciente del espacio virtual puede aportar integridad y vitalidad a la identidad étnica. Además, ha unificado, despertado y demandado a las etnias en todas las fronteras nacionales debido a la historia y la identidad mutuas. Según los resultados de la investigación, la pertenencia étnica de los estudiantes kurdos y turcos fue mayor que la de otros, y estas etnias tienen una conciencia más completa sobre su historia, épica, tierra, costumbres étnicas, rituales, industria, estilo de ropa y cocina local. Además, se adhirieron al matrimonio, la asociación y la cooperación con su gente y estaban orgullosos de sus nombres nativos.
\end{abstract}

Palabras clave: identidad étnica, socialización moderna, estilo de vida moderno, identidad moderna, modernidad, uso de redes sociales virtuales. 


\begin{abstract}
Ethnicity and nationality are types of modern social identities that have reformed after being globalized. This research tries to study the role of modernity characteristics on ethnic identity. Research data was collected using a researcher-made questionnaire, and 384 students of Islamic Azad University, Tehran North Branch were selected by non-probability random sampling in 2019. The results show the significant relationship between ethnic identity and modernity characteristics, modern lifestyle $(r=-0.66)$, modern identity $(r=-0.74)$, modern socialization $(\mathrm{r}=-0.40)$, and purposeful use of virtual social networks $(\mathrm{r}=0.31)$. In other words, ethnic identities are weakened by the tendency of participants to the western beneficial and individualistic patterns and values adapted with law, avoiding and underestimating religious and traditional norms. Meanwhile, virtual social networks as a modernity tool have been an opportunity to state the ethnics political and social demands particularly frontiersmen such as Kurds and Turks. Principally, they have appeared in the form of dramatic movements and inter-ethnic tensions that following modernity elements finally reduces ethnical belongings and tendency to the global identity, and only purposeful and conscious use of virtual space can bring integrity and vitality of ethnic identity. In addition, it has unified, awakened, and sued ethnics all over the national borders because of mutual history and identity. According to the results of research, the ethnic belonging of Kurdish and Turkish students was higher than others, and these ethnicities have more complete awareness about their history, epic, land, ethnic customs, rituals, industry, style of clothing, and local cuisine. In addition, they adhered to marriage, companionship, and cooperation with their people and were proud of their native names.
\end{abstract}

Keywords: ethnic identity, modern socialization, modern lifestyle, modern identity, modernity, use of virtual social networks

\title{
Introduction
}

Ethnic identity is considered as one of the intermediate identities in the modernity era which is beyond the individual identity and is lower than national identity. It has changed its nature and separated from its intrinsic form by renaissance and the formation of the industrial revolution, urbanization, religious reform, political revolutions, the emergence of modern governments, etc. In addition, it gets the fluid form as people in the modern world get enabled to select different identities for themselves, and ethnic, national, religious, and other identification labels (Mahdavinezhad et al., 2010: 116). The multiplicity and diversity of identity have been a reality in the vast majority of societies in the past and present. In contemporary, the varieties of identity not only do not reduce despite innovation processes, and establishment of modern institutions, but also they have changed to the topic of controversy and identical differences. Moreover, the globalization processes such as the daily incremental expansion of media, getting out of the monopoly of media management, and control in the second half of the 20th century increased identity awareness and their representation possibility. Accidentally, it increased the identity majority and varieties along with the other cultural and social evolutions (Beheshti and Haghmoradi, 2017).

Iran has various languages, dialects, cultures, sub-culture, tribes, clans, and races. The existence of 29 languages, Kurdish, Turkish, Baluch, Turkmen, Arabian, Lor, and Persian 
tribes, countless diversity of cultural areas and racial diversity, and coexistence of ethnicities show Iran civilization. Today, ethnic identity and ethnocentrism has been changed to one of the vital problems of the world. Ethnicity is a social product and people's historical experience in the modernization and globalization process and has an important role in forming awareness, making individual and group memory that is remained from the group tradition. The identity meaning has faced with crisis influenced by changing the lifestyle caused by modernity. Ethnic identities have known itself in this gap vulnerable to discrimination and injustice because of political, economic, cultural, and religious reasons. Or, they have a claim of priority or forgotten because of national identity priority, farness, religion, etc. So they use modernity tools (virtual media) to express their cultural and ethnic culture, seeking identity, and connecting the tribes in various borders. Or, they use virtual media to express their identical claims and complaining movements.

Modernity is changing the lifestyle where people can select their identity freely and based on the intellect and reason far from the traditional values. Studies have shown that the more members of the group belong to their ethnicity and ethnic identity, not only the more their ethnic identity in the modern world will not be eliminated, but also they will be able to represent and renew it. Any evolution such as modernity influences people's ethnic identity and can change a part of its identity. However, it can't eliminate the ethnicities in modern and global identity. According to Chalabi (2003), the positive heritages of modernity has brought the world nations and people closer and changed the world to the global village. These include increasing the density of international and states relationships, expanding mass communications, means of transportation, expanding and rapidly exchanging world information in various fields, virtualizing the relationships in international levels, expanding formal education and literacy in the world, increasing familiarity of the people of the world with the customs, history, and culture of different nations, increasing generalism, and generally generalizing spatial tendency, expanding information highways, and the ease of access to them around the world in the world increase cultural and native identities interactions. They also have changed the world to the unified network of social relationships that has established a flow of human meanings between different regions (Chalabi, 2003: 308).

According to Jenkins (1996), modernity and globalization have occurred due to factors and mechanisms such as the emergence and increasing progress of virtual society, a kind of identity, and meaning crisis in different societies of the world. Therefore, various people and social classes seek methods and policies to solve this crisis including various forms of cultural specialism. Actually, globalization, by space and time reconstruction, making border permeable, and significant expansion of social spaces eliminate the essential conditions for identification, and traditional meaning construction to the great extent, makes the identity and 
meaning crisis which make the identity reconstruction inevitable. Some people know to cope with crisis only by depending on resourcing to the traditional methods and resources of identification. Therefore, it provides the proper social condition for various forms of specialism ethnic stresses and identical crises (Rezaei and Dilmaghani, 2018). Modernity has various positive and negative aspects. In other words, it is both an opportunity (in the distribution and access of individuals to educational facilities and information and technology, transferring and exchanging of values and cultural goods and so on) and a threat (cultural unification, varieties removal, and digital gap increase). Global networks publish mass culture from one hand and are a source of nutrition for the elite of society with the aim of innovation and invention, challenge culture, and supply the identity needs well by removing local and time aspects. In addition, various borders of social life can damage and change ethnic and national identity, but modernity can reinforce modernity and modernity characteristics in case of having proper and conscious percept about it. In this regard, dynamic identity and a healthy society depend on the level of national affiliation and belonging of members of society especially the youth.

In sum, this research tries to study the effect of modernity characteristics on the ethnic identity of students of Islamic Azad University, Tehran, since students are considered as the open-minded social class of a society who are sensitive to the social and political issues of the society, are interested so much on their political wills and ideas, and the university is a crossroads of different ethnicities. Students can state their ethnic thoughts and cultures and change their identity in interaction with the other students' ethnics and culture. Or, they can rethink their identity, and social and cultural changes of this generation are the origin of the change in the other aspects of society. The principal objective of this research is to study the role of modernity characteristics (modern identity, modern lifestyle, and modern socialization) on the ethnic identity of students and to study the ethnic belonging among participants.

\section{Review of literature}

Modernity is a cultural tendency in economic, political, social, scientific, and so on fields with the emphasis on all-aspect freedom of humankind as well as reliance on the human intellect, giving originality to a person, and a special experience of life that is independent of time and place. According to Habermas's idea, modernity is being and living in this era as modernity characteristics have changed the ethnic identity more than national identity. Then, some studies about modernity elements and ethnic identity are mentioned.

Results of Keyhan et al. (2019) research showed that students with high perceptions about ethnic and cultural significance, ethnic- political action capacity, opportunities, and ethnic costs used Telegram application to exchange political information and ethnic demands and to republish their ethnic status. Of course, social networks are only a tool to represent the 
ethnic identity that unifies and reinforces ethnic identity besides structural reasons such as relative deprivation, dissatisfaction, injustice, and experience of people's lives.

Alipour et al. (2016) believe that modernity and culture globalization challenge national belonging and values of society by an increasing sense of deprivation, discrimination, right-seeking, and magnifying the events of the Kurds. Modernity tools and elements reinforce the Kurds political identity by a focus on the political field of Kurdish ethnic identities such as importance and maneuvering in the field of formation of local parties, participation, and seriousness of Kurdish political demands, the priority of Kurdish films to Iranian films, and are the most correct Kurdish representatives in the elections. In addition, their ethnic identity is weakened by attracting them in the global field, injecting the western pattern and values, individualism, rationalism, and attracting young people to use western products, modern, and western identity.

According to Nurroddin and Zahedi (2015), modern lifestyle invites people to follow similar-to-western lifestyle and pattern which is in contradiction with the traditional and national lifestyle by changing the leisure time style, tendency to consumerism, exhibitive life, shopping pattern, nutrition style, and attention to appearance (appearance management). In modern society, people connect to the global community through their social media, follow the western lifestyle, values, and patterns willingly or unwillingly, and their national and ethnic belongings are gradually weakened for the tendency to the global culture and identity.

Results of Shafieinia's research (2015) show that modernity and the incremental development of information and communication technologies have evolved identity-seeking and growth of ethnic specialism. In recent years, Kurds have used virtual social networks as a tool for identity specialism growth. Most internet contents are for demonstrations, campaigns, political-cultural activities, ethnic tendencies, or related to Kurdish culture, history, and society that invite Kurds to separatism and nationalism. Actually, modernity influences Kurdish thoughts by changing values and attitudes toward the ethnic identity and emphasis on the political aspect and ethnic supremacy. This matter only reassembles the Kurds not reinforces ethnic identity. According to Ansari et al. (2014), modernity, globalization process, and virtual space increase crisis, ethnic tensions, and uprisings by changing the traditional framework and condition of identification. Modernity supplied the ethnic identity needs by increasing identity-making resources that were ethnic in the past, and emphasis and advertisement of principals such as freedom, equality, human rights, democracy, and living in the contemporary world that threatens the human and cultural varieties and weakens the ethnic identity. Khajenuri et al. (2013) believe that social media as a modernity tool are active agents forming the beliefs and attitudes and media provide human access to various resources. This access makes a threat in the previous identity resources and forms a new identity. The ethnic identity is challenged in light of the world and social media and forgets some ethnic 
values and traditions.

Results of Bagheri et al. (2012) show that Ahwaz citizens have faced with identity crisis today by experiencing the communicative-technological identification space. People tend to a convenient and luxurious life and western cultural values increase and people belongings to identities and traditions reduce. Tavasoli and Adhami (2012) believe that youth generation in the new era doesn't have specific ethnic memories for use of global tools such as satellite, cell phone, and cyberspace, and inexperience of political and social events. They become socialized based on rationalist and modern values and tend to have a fluid identity.

According to Nassaj's idea (2008), globalization has changed to a resource and a factor to develop the ethnic awareness and conflicts in the world which weakens and humiliates the ethnic identity. The identification condition is evolved in the globalization process. People hesitate to select their lifestyles among the rest and try to rely on the traditional identification tools and resources to escape the identity crisis.

According to Ariely's idea (2019), ethnic identity is a type of collective identity which originates from the past symbols, related memories, and values of a specific territory that differs itself from the other countries and doesn't easily melt into a global culture. If we become consumers of global goods, services, information, and culture and don't produce content in this area, we will seek a homogeneous global identity. Actually, personal belonging reduction to the national identity and people problems for the place will reduce the status of ethnic and national identity and prefer the global identity.

Results of Yuki research (2015) show that innovation increases the ethnic conflicts, fights, and ethnic and global dominance on the national identity and the development of the global. In addition, same identity has weakened the ethnic identity. Innovation, by changing lifestyle, industrial production (production style change), interaction way, education, urbanization, promoting and benefiting from communication and information technologies, and consumerism, has changed and sometimes destroyed some of the values, traditions, and dominant lifestyles of ethnicity, and increased the gap between national and ethnic identity. Innovation has evolved the ethnicity perception about its present condition through soft power, comparability of tribes, and making the gap between ethnicity and nation and has increased ethnic stress.

According to Gündüz (2017), virtual space is a place of expressing the users' political and social demands. Users not only use this space for a hobby, but also represent the realities by expressing reality, sharing life stories, events, and profiles regularly and interactively. In addition, people express their emotions, thoughts, ideas, and their activity, and presence in this space influences the change and obstruction of users' identity.

Boháč (2010) studied the role of servers and web pages all over the world for increasing stress and fight about the ethnic identity of the Assyrians by referring to the ethnic 
identity of the Assyrians. In addition, he believes that Assyrians, who had to travel in the past due to ethnic conflict and tensions in the Middle East and tolerated many problems, can today use the virtual space and satellite channels for ethnic integration, representation, and survival of Assyrian ethnicity of Kurdistan, Turkey, and the Middle East.

According to Conversi (2010), modernization of communities and globalization indirectly increased the stress and fight of ethics, globalization, and Americans after encouraging individuals to nationalism and patriotism. Cultures globalization deformed and intensified the ethnic fights and the caused capitalism growth by globalization and led to cultural poverty and tempting people for ethnicity. Modernity increased the identity crisis and reduced the ethnic belonging using the cultural tool, advertising the western lifestyle (being Hollywood), and its symbols as an utopia.

Results of Foller research (2009) show that globalization in Amazon is a process that was started by colonial intervention in the Amazon, damaged living conditions, made inevitable human and natural disasters, and took the selection power from a lifestyle of Amazon tribes. Amazonian youth who moved to the cities forgot their language, surname, and cultural manifestations which connected them to their ancestors. According to his idea, ethnic survival in the modern world is possible if they recognize the innate dignity ethnicity. In addition, the tribes' difference seems as their power, and tribes can use the technological tools to transfer their traditional thought and knowledge by increasing knowledge, and use the free space to get rid of limitation instead of melting in the global culture.

According to Boyd (2001), modernity influences the cultural evolutions by rationalism, critical thinking, and emphasis on global facts. Modernity challenges people's identity through the globalization and communicative tools and increases self-awareness and ethnic tendencies, and freedom from the compulsory identity. Modernity increases individualism from one hand and has led to the awakening and demand of ethnicity and the strengthening of ethnic identity, especially from a political point of view on another hand by increasing people's awareness and knowledge about the relative deprivation, injustice, and compulsory oppression on ethnic identity.

\section{Theoretical bases}

Modernity includes cultural resources, modern socialization, modern identity elements, group-relationship structure, and modern lifestyle. Scholars introduced the rise of capitalism and technology, the rise of liberalism and individualism through the creation of the social contract, materialism, rationalism, egalitarianism, and sentimentality as the modernity characteristics (Rudposhti et al., 2014: 3).

Based on Robert G. Dunni idea, identity sustainability in the modern era is influenced by eclectic consumerism, growth of talents, selections, different lifestyles, immigration, 
transnational capital, communication technology, cultural exports, democracy, social movements, changing class arrangements, and changing the authority and full authority of traditional identities (Dunn, 2005). According to his idea, modernity has flourished individualism and human freedom in addition to creating the potential condition. In addition, it was the supporter of any type of individualism ideology which was neither adapted with its ideological beliefs nor its proposed constructivist theories about education and social control (Dunn, 2006). According to Hall (2004), modernity is similar to the national government that wants to integrate the culture and imposes its cultural homogeneity with the other communities. However, various communities and people don't leave their identity elements easily and even show their local cultures by media to the cultures of other communities because they have specific interest in their identity resources (national and global crosscultural exchanges). Interest in ethnic identity and use of social networks (virtual space) influences the ethnic attitude of users, and this space is for representation and revives the hidden part of ethnic and local identity for the political awakening of ethnic identity (Hass, 2004). Harvey starts the globalization theory by disrupting the traditional order of space and time and believes that gap is formed in the traditional and modern eras by changing the nature of space and time, and the globalization process is considered as the main factor of cultural specialism. It has changed the identification process in the present world by changing the traditional conditions and framework of identification, weakening, and damaging the traditional resources and factors of identity.

Based on Carl Deutsch's idea, intensification of the modernity process and globalization has led to the incremental changes in personal and social life and evolved the attitudes, expectations, and wills of people in various groups. Modernity characteristics such as education increase, political participation, literacy, and urbanization change the traditional communities (ethnic identity). The innovation process influences the socialization process, and the socialization process as well as forms the political behaviors and attitudes. In addition, political mobilization in this period is based on urban and collective identity that damages the old loyalty and gradual deterioration of traditional values (Vaghari, 2019: 235).

Anthony Giddens knows modernity as the most pervasive reality of this era and a promising opportunity for humans, a factor of dangers for humans. According to his idea, modernity is a double-edged sword that makes modern social institutions evolved and its global development, greater opportunities, and conditions for a human to use a reliable, healthy, and safe life. However, modernity changed people's identity through the development of urbanization, change of selections, emphasis on rationalism, industrialization, progress in communication, and information technology on the other hand and made many dangerous phenomena (Daryapour 2001).

According to Giddens, one of the most important characteristics of modernity is 
people's decisions to be empty of divine and traditional backing. Instead, their decisions should be rational, secular, and in light of modern information and knowledge. This is the exact forming substance of the main core of rethinking modernization. In this regard, personal identity in the modern era is a frequently worked phenomenon by people. It means humans are constantly creating and correcting their identities and constantly reviewing who they are and how they have become (Giddens, 2005). The globalization of information and communication technologies has made people in different places aware of lifestyles, values, and behavioral norms of other regions of the world. This matter can change or reinforce the lifestyles, values, and norms (Giddens, 1998). Modernity is radically changing the quality of the daily lives and influencing the most private experiences. Modernity deeply penetrates people's emotions and identity's heart, and personal identity is influenced by the social conditions of the modern world. In addition, the global culture let cultures know themselves and reinforce their local self-consciousness, tend to the coexistence of culture, the use of the heritage of civilization, and world culture. In this regard, rationalism is directed toward the teachings of global strength, local consciousness, and the expression of "think global and act locally."

Regarding Waters, modern space and globalization are a social process where people get free of geographical constraints on social and cultural relationships, and they increase people's consciousness. According to his idea, three main characteristics of the capitalistic system are industrialization, rationalization of characteristics, and lifestyle. In addition, desecration, rationalization, materialism, increasing interactions, and expanding the scope of communication are the main principles of modern life. Moreover, people are constantly connecting with many people (strangers) through global tools (such as virtual social networks). However, the expansion of modernity is in a way that parts of human life get meaning in the global frame (globalization). Alternatively, value systems (culture), economic transactions system (materialism), and political systems (emphasis on values such as freedom, democracy, and human rights) have been evolved in this space (Waters, 2000). The consumer's governance has moved various institutes, governments, and communities toward symbolic cultures and signs. McDonald's, denim clothing, pop music, etc. are cultural symbols that impose consumer domination on different communities and make a kind of homogeneity between different communities. Of course, this homogeneity is mixed with the differences and leads to human cultural unity and form. In other words, modernity tools and globalization miniaturize the world (space and place removal), individualism (increasing interactions without selection border and range), homogeneity (homogeneity of consumption taste), and globalization (the possibility of using any tribes and group of technologies). These technologies (virtual social networks) make it possible for people to stay in the waves of values and symbols. They introduce varied cultures to people, and people find their values 
and identities from this path. In addition, humans expose themselves against various cultures directly.

According to his idea, modernity and an increasing range of cultural communications don't remove and homogenize cultures but change identity elements easily and as a result lifestyle and consumption taste based on the policies of the community. In addition, deficiencies and shortcomings of the government from one hand, and global tools, increasing communications, immigrations, ethnic fields (fading religious values), the world shortage, and emphasis of modernity on the thoughts, and freedom changed the political part of ethnic identity and identity-seeking.

\section{Methodology}

The methodology is quantitative-surveying. The statistical population of this research includes all students of Islamic Azad University, Tehran North Branch that was 35.126 people according to the public relations report of the university. 384 students were selected as a sample volume by the Cochran formula, and the sampling method is non-probability random sampling. The research tool is a questionnaire (the researcher-made questionnaire), and an analysis unit is at the micro-level. The reliability and validity of the questionnaire were confirmed by the scholar professors in the final questionnaire. The indexes have face validity. The validity of the main indexes of research was confirmed by the internal reliability method, and Cronbach's alpha coefficient technic was used that was higher than $70 \%$ and acceptable.

\section{Findings}

\section{According to the descriptive findings}

According to the descriptive results, the mean of half participants using social networks 1-2 $\mathrm{h}$ per day, the maximum use was $8 \mathrm{~h}$, and the minimum use was $1 \mathrm{~h}$ per day and night. Instagram application is the most used and popular application among users based on $87.2 \%$ of participants' views. Users use the virtual space mostly to contact with friends, relatives, and hobby, share their real ideas, and social, economic, and political demands. Based on Table 1 and mean values of variables, about half of participants use virtual space in a medium level for fundamental values of modernity, belief in gender equality, religious equality, belief in the naturalness of cultural and social change and belief in democracy, political participation, human rights, individualism, materialism, rationalism a tendency to western societies, imaging themselves as a world (modern identity), accepting global norms and values and emphasizing political participation, political knowledge and political attitudes (modern socialization), a desire to emulate the western style of dress and makeup, consumerism and theatrical consumption, luxury-orientation, interest in having a unique look and desire for web browsing, use of virtual networks, street strolling, shopping malls, going to 
a coffee shop, relaxing and going to luxurious sports and leisure centers to earn prestige, and sedentary and theatrical life (modern lifestyle). However, people's interest in the use of western cultural products, interests, and belonging to the ethnic identity is high.

\section{Table 1}

Distribution percentage of participants based on tendency to the ethnic identity and modernity elements

\begin{tabular}{cccccc}
\hline & Variables & Mean & Median & Mode & St. dev \\
\hline Ethnic & Social identity & 31.47 & 32 & 32 & 5.87 \\
identity and & Political identity & 33.98 & 34 & 37 & 6.33 \\
its aspects & Cultural and historical identity & 16.52 & 16 & 16 & 3.46 \\
& Ethnic identity & 81.69 & 81 & 78 & 12.17 \\
& Consciousness & 9.40 & 10 & 11 & 2.11 \\
Modern & Cognitive aspect & 11.20 & 11 & 8 & 3.24 \\
identity and & Social aspect & 12.82 & 12 & 11 & 2.62 \\
its aspects & Western attitude & 13.27 & 13 & 12 & 3.32 \\
& Globalization & 13.19 & 13 & 14 & 3.19 \\
& Modern identity & 59.88 & 59 & 57 & 9.28 \\
Modern & Theatrical consumption & 10.90 & 11 & 12 & 3.67 \\
lifestyle and & appearance management & 14.99 & 15 & 15 & 4.42 \\
its aspects & Leisure style & 12.53 & 12 & 12 & 3.25 \\
& Cultural consumption & 9.32 & 9 & 9 & 2.14 \\
Modern & Modern lifestyle & 51.20 & 51 & 52 & 8.96 \\
socialization & Cultural socialization & 14.62 & 15 & 13 & 3.22 \\
and its & Political socialization & 8.86 & 9 & 7 & 2.55 \\
aspects & Modern socialization & 23.47 & 23 & 24 & 4.21 \\
\hline
\end{tabular}

First hypothesis: there is a significant relationship between modern socialization and ethnic identity $(r=-0.40)$ based on the Pearson test. In other words, the participants' interest and tendency to the ethnic identity reduce by increasing their tendency to the global norms and values, individualism political attitude, and global logic (modern socialization). Furthermore, the maximum effect is on the political socialization $(\mathrm{r}=-0.61)$.

Second hypothesis: there is a significant relationship between the purposeful use of social networks and a sense of belonging and tendency to the ethnic identity. In other words, activity and content production in the virtual space in the ethnic field and interaction with tribes for the ethnic demands and awareness reinforces the ethnic identity. 


\section{Table 2}

Pearson test between the modern socialization and ethnic identity

\begin{tabular}{cccccc}
\hline Variable & $\begin{array}{c}\text { Cultural } \\
\text { socialization }\end{array}$ & $\begin{array}{c}\text { Political } \\
\text { socialization }\end{array}$ & $\begin{array}{c}\text { Modern } \\
\text { socialization }\end{array}$ & $\begin{array}{c}\text { The purposeful } \\
\text { usage of virtual } \\
\text { networks }\end{array}$ \\
\hline $\begin{array}{c}\text { Ethnic } \\
\text { identity }\end{array}$ & $\mathrm{r}$ & -0.019 & -0.614 & -0.402 & 0.318 \\
\hline \multicolumn{2}{r}{ No. } & 0.714 & 0.000 & 0.000 & 0.021 \\
\hline
\end{tabular}

Third hypothesis: there is a significant relationship between modern identity and ethnic identity $(r=-0.74)$. In other words, the participants' tendency to the ethnic identity reduces by increasing their tendency to the modern identity (accepting the modernity elements of equality, legitimacy, denial of religious and family values, western human rights, individualism, the tendency to the globalization, and western attitudes). On the other hand, the participants; interest and belonging to their ethnicity increases by increase the global consciousness

\section{Table 3}

Pearson test between the modern identity and ethnic identity

\begin{tabular}{cccccccc}
\hline \multicolumn{2}{c}{ Variable } & $\begin{array}{c}\text { Global } \\
\text { consciousness }\end{array}$ & $\begin{array}{c}\text { Social } \\
\text { aspect }\end{array}$ & $\begin{array}{c}\text { Cognitive } \\
\text { aspect }\end{array}$ & Globalization & $\begin{array}{c}\text { Western } \\
\text { attitude }\end{array}$ & $\begin{array}{c}\text { Modern } \\
\text { identity }\end{array}$ \\
\hline Ethnic & $\mathrm{r}$ & 0.206 & -0.537 & -0.459 & -0.655 & -0.605 & -0.747 \\
identity & $\mathrm{Sig}$ & 0.000 & 0.000 & 0.000 & 0.000 & 0.000 & 0.000 \\
\hline \multicolumn{2}{c}{ No. } & 384 & 384 & 384 & 384 & 384 & 384
\end{tabular}

Fourth hypothesis: there is a significant relationship between ethnic identity and modern lifestyle (-0.66). In other words, the participants' interest and tendency to the ethnic identity reduce by increasing their tendency to the modern lifestyle (consumerism, the tendency to the theatrical consumption, luxury-orientation, body management, the tendency to the sedentary life, the use of western cultural products). In addition, the maximum effect was for appearance management.

\section{Table 4}

Pearson test between the modern lifestyle and ethnic identity

\begin{tabular}{ccccccc}
\hline \multicolumn{2}{c}{ Variable } & $\begin{array}{c}\text { Theatrical } \\
\text { consumption }\end{array}$ & $\begin{array}{c}\text { Appearance } \\
\text { management }\end{array}$ & $\begin{array}{c}\text { Leisure } \\
\text { style }\end{array}$ & $\begin{array}{c}\text { Cultural } \\
\text { consumption }\end{array}$ & $\begin{array}{c}\text { Modern } \\
\text { lifestyle }\end{array}$ \\
\hline $\begin{array}{c}\text { Ethnic } \\
\text { identity }\end{array}$ & R & -0.416 & -0.659 & -0.341 & -0.456 & -0.664 \\
\hline \multicolumn{2}{c}{ No. } & 0.000 & 0.000 & 0.010 & 0.000 & 0.000 \\
\hline
\end{tabular}

\section{Discussion and conclusion}

Modernity means rationalism and attempts to make everything rational, breaking social habits, and traditional beliefs by passing values, senses, and beliefs; in one word, the materialized and intellectual methods of an old life. Modernity is an intellectual approach and 
responsible for a specific level (Ahmadi, 1998: 11). Based on the results of research, modernity weakens the ethnic identity by an emphasis on the values of rationalism, materialism, individualism, westernism, globalization, the denial of modernism, giving priority to legal norms, political knowledge instead of traditional values, following the global patterns, individual utilitarianism (modern socialization), promotion of theatrical and luxurious life, attention to appearance, consumerism, and tending to a comfortable and sedentary life (modern lifestyle). Furthermore, there is a significant relationship between modern socialization and tendency to the ethnic identity of participants that are in agreement with the results of Rezaei, Amenluei, and Dilmaghani (2018), Nuroddin and Zahedi (2015), Shafieinia (2015), and Tavasoli and Adhami (2012) research. According to Rezaei, Amenluei, and Dilmaghani (2018) research, the development of communications, promotion of virtual space, and modernity changed ethnicity such as intensification of ethnicity, excessive ethnic identification, the fragility of the nation- government pattern, the gap in the national identity, generalization of gaps, social and ethnic divisions, reverse movement from society to socialization, imposing unequal cultural relations, and increasing surplus value in cultural exchanges. Moreover, Nuroddin and Zahedi (2015) believe that modernity tools weaken the ethnic identity by advertising modern lifestyle, injecting the western and individualism values, emphasis on freedom, personal independence, and individualistic benefits. Shafieinia (2015) also believes modernity influences on Kurdish tribe by changing the attitudes and values toward ethnic identity, emphasis on the political aspect, and seeking ethnic supremacy which only reassembles Kurds and doesn't reinforce the ethnic identity. Of course, according to Keyhan et al. (2019), Beheshti and Haghmoradi (2017), Gündüz (2017), Boháč (2010), and Namdari (2018), the purposeful use of the global tool (virtual social networks) reinforce the ethnic identity.

According to Namdari (2018), following and membership in the mutual virtual social networks and content production according to the ethnic elements and values of the Lak tribe integrate them in this space. Based on Conversi (2010), modernity is like a catalyst that both reinforce ethnicity and national and ethnic mobilizations. Globalization reduces inter-ethnic relationships and involvement and increases dissatisfaction of lifestyle using cultural tools such as movies and TV channels (satellite), advertising consumerism, American symbols, western lifestyle, internet, increasing interactions, introducing American lifestyle (becoming Hollywood), and its symbols as a utopia. If the ethnicities can raise their children based on their ethnic traditions and values and live along with national security, they use the global tools to advertise and unify tribes and justice-seeking. Otherwise, they will be eliminated from the global culture and ethnic conflicts will lead to genocide.

Other results of this research are about the relationship between modern lifestyle and belonging to the ethnic identity which is in agreement with the results of Nuroddin and Zahedi 
(2015), Nassaj (2008), Boyd (2001), and Foller (2009) research. According to Boyd (2001), modernity changes and makes people's diversityism, and tendency to show off and live in multicultural metropolises. In addition, they have directed a similar and homogeneous life to the colorful and modern life including the western lifestyle.

According to the findings of Alipour et al. (2016), Yuki (2015), Khajenuri et al. (2013), Ansari et al. (2014), and Bagheri et al. (2012) research, people ethnic identity is weakened by their tendency to the global and modern identity. According to Ansari et al. (2014) idea, globalization threatens the human values systems of ethnics and nations by the value and dominant political system, which is in a conflict of the human dignity, cultural freedoms, symbolic systems of social identities, and ethnic groups in the value system. These form the extremist religious fundamentalist movements and various identities and threaten the ethnic identity. Furthermore, Alipour et al. (2016) believe that modernity and globalization weaken the ethnic identity by stimulating Kurdish political emotions, magnifying events, injecting western patterns and values, individualism, rationalism, and attracting young people to use western products, modern, and western identity. According to Giddens's idea, modernity is both a reinforcing and weakening factor of ethnic identities. The global culture makes the cultures know themselves, reinforce local self-consciousness, coexist with the culture, and use civilization heritages, and the global culture using the modernity tools. In addition, they turn to the teachings of global strength, local consciousness, and the expression of "think global and act locally" based on rationality". Meanwhile, a part of ethnic identity may be weakened or eliminated, and modernity and its elements can attract ethnicities in the global ethnicity in case of a reduction of personal belonging to the ethnicity.

Based on Hall (2004), globalization of communication and relationship technologies has made people in various regions be aware of the lifestyles, values, and behavioral norms of the other regions of the world. This matter can lead to the evolution of lifestyles, values, and norms. These technologies are the main factor in providing global culture, and cultural relativity. The cultural globalization increases the importance of regionalism, nationalism, ethnicism, decentralization, and assignment of authority.

The dominant democratic space on social networks has softened or marginalized the ideas of extremist groups. The most important opportunities of social networks in the ethnic field are providing inter-ethnic interaction and discussion and the possibility of mutual recognition and understanding of cultural differences. Virtual networks are a proper opportunity to reflect the culture, propose ethnic demands, increase the power and possibility of ethnic mobilization, create content in ethnic language, and promote ethnic symbols, ethnic demand, and so on. These opportunities can be used to protect and globalize the ethnic identity by social activities (introducing and celebrating ethnic celebrities, environmental concerns, and social issues), and cultural and historical activities (publication of literature and 
ethnic epics through storytelling, poetry, and rituals (foods, local clothing, local songs, etc.)) instead of absorbing in their target and global identity along with the global values and emphasis on the political values. Users often join ethnic groups and political movements to exchange information and represent the ethnic culture and believe that virtual spaces are the opportunity of expressing and reflecting deprivations, successes, arts, concerns, and are a factor of promoting the sense of empathy of so-ethnics. Replacing cultural coexistence with the globalization of culture can remove the false performances of culture globalization such as internal disunity, the extreme tendency to western culture, reduction of trust in national governments, and a sense of relative deprivation among minorities, ethnicities, and Muslim communities.

\section{References}

Ahmadi H., (1999), Ethnicity and ethnocentrism in Iran, from myth to reality, Tehran: Nashre- Ney.

Alipour A., Saadati Jafarabadi H., Jabbari H., (2016), The process of cultural globalization and its effect on the national and ethnic identity of the Kurds from the graduate students of universities' view in Kurdistan Province, Journal of New Attitudes in Human Geography, 8(4): 75-61.

Ansari A., Hashemifar A., Rezaei Amenluei H., (2014), Analysis of ethnic identity crisis in Iran in the globalization condition and virtual space by the science of sustainability approach, The Specialized Journal of Social Sciences, 8(2): 160-131.

Ariely, G. (2019). The nexus between globalization and ethnic identity: A view from below, Ethnicities, Nationalities Papers 31(4):1-21.

Bagheri M., Hosseinzadeh A., Hashemi N., (2012), Study of the globalization effect on the ethnic identity, Social development, 7(1): 89-108

Beheshti S., Haghmoradi M., (2017), Trans-analysis of the related studies to the relationship between ethnic identity and national identity in Iran with emphasis on the role of media, Iranian social issues, 8(2): 27-5.

Boháč, A. (2010). Assyrian ethnic identity in a globalizing world, In Beyond Globalization: Exploring the Limits of Globalization in the Regional Context (conference proceedings), Ostrava: University of Ostrava Czech Republic,. http://conference.osu.eu/globalization/publ,2(1): 67-72.

Boyd, D. (2001). Reflections on the Impact of Modernity in Evolving a Multi-faceted Individual Identity, Modernity, Postmodernity \& Capitalism, Econometrica, 78(1):1121.

Chalabi, M., (2003), Sociology of Order, Tehran: Ney Publications.

Conversi, D. (2010). Globalization, ethnic conflict, and Nationalism. Online 
at:,www.researchgate.net/publication/231537078_Globalization_ethnic_conflict_and_n ationalism

Daryapour Z., (2001), The place of tradition and modernity in the value system of youth and adults in Tehran. Tehran: Secretariat of the Public Culture Council.

Dunn R., (2006), Consensual critique of postmodernism. Tehran: Jahan Ketab Institute

Foller, M. (2009). Ethnic groups and the globalization Process - Reflections on the Amazonian groups of Peru from a human ecological perspective, American Antiquity, 46(2): 52-67.

Giddens, A., (1998), The third way, reconstruction of democratic sociality. Tehran: Shiraze publication

Giddens, A. (2005), The consequences of modernity. Tehran: Ney publication

Gündüz, U. (2017) The effect of social media on identity construction, Mediterranean Journal of Social Sciences 8(5): 85-92.

Hall, S. (2004). The old and modern identities. Tehran: Cultural Studies and Research Institutions.

Keyhan, A., Forghani, M., \& Mozaffari A., (2019). The role of cell phone social networks in reproducing the ethnic identity of Kurdish students at Tehran Universities, Journal of Modern Media Studies, 5(18): 29-79.

Khajenouri, B., Khodabakhshi Hafshejani, N., \& Parnian L., (2013). Relationship between group media and ethnic identity with women's national identity (Case study of women in Kermanshah), Specialized Journal of Social Sciences, 7(4): 180-157.

Mahdavinejad, M., Nehmanian M., \& Khaksar N., (2010), Architect's identity, determining the meaning of identity in pre-modern, modern, and postmodern eras, Journal of city identity, 5(7): 122-113.

Namdari, M., (2018), Interaction in virtual social networks and its effects on the ethnic identity (case study: Lak tribe), Journal of management and culture, 11(41): 1-17.

Nassaj H., (2008), Globalization and Iranian tribe identity with emphasis on the language and tradition components, The theoretical policy research, 1(5): 129-156

Nurroddin A., Zahedi M., (2015), The effect of lifestyle on ethnic identity (case study in Lorestan Province), Iranian Journal of Sociology, 16(3): 65-91.

Rahnamay Rudposhti, F., Banimahd B., \& Mirsaeedi J., (2014), Modernity and Management Accounting, Journal of Management Accounting and Auditing Knowledge, 3(12): 13-1.

Rezaei Amenluei, H., Dilmaghani F., (2018), Analysis of the crisis of ethnic identity in Iran in the globalization condition and cyberspace with the approach of sustainable science, Journal of Politics, 5 (17): 127-105.

Shafieinia A., (2015), Consequences of Virtual Social Networks (Case Study of Kurdish National Identity and Ethnic Identity), Political Research, 2(13): 21-1. 
Tavasoli, G., Adhami, J., (2012), Historical Memory, Ethnic Identity and Globalization: Intergenerational Research in Sanandaj, Social Issues in Iran, 3(2): 37-7.

Vaghari A., Sarukhani B., Koldi A., (2019), Sociological determination of the relationship between modernity and subjective welfare of the staff of the Social Security Organization, Journal of Social Welfare and Development Planning, 10(38): 254-219.

Vaghari, A., Sarukhani B., Koldi A., (2019). The sociological determination of modernity relationship and subjective welfare of the subjective welfare of social security organization employees, Journal of welfare and social development planning, 10(38): 254-219.

Watzer M., (2000), Globalization. Tehran: Industry Management Organization.

Yuki, K. (2015). Modernization, Social Identity, and Ethnic Conflict, Munich Personal RePEc Archive, Online at https://mpra.ub.uni-muenchen.de/67316/ 